\title{
VERNACULAR ARCHITECTURE AS A FORM OF RESILIENCE IN CHINESE COUNTRYSIDE TRANSITION. EVIDENCE FROM A RURAL SETTLEMENT IN THE FUJIAN PROVINCE
}

\author{
G. Semprebon ${ }^{1,2,3}$, * L. M. F. Fabris ${ }^{1,4}$, W. Ma, ${ }^{2,}$ *, L. Long ${ }^{3}$ \\ ${ }^{1}$ Department of Architecture and Urban Studies, Politecnico di Milano, Italy - gerardo.semprebon @ polimi.it, \\ lucamariafrancesco.fabris@polimi.it \\ ${ }^{2}$ School of Design, Shanghai Jiao Tong University, China - mwj@ sjtu.edu.cn \\ ${ }^{3}$ Beijing Advanced Innovation Center for Future Urban Design, Beijing University of Civil Engineering and Architecture, China - \\ longlin@tntlab.cn \\ 4 北京建筑大学海聚专家 - Beijing University of Civil Engineering and Architecture Haiju Expert
}

Comission II - WG II/8

KEY WORDS: Vernacular, Rural, Fujian, China, Resilience

\begin{abstract}
:
Chinese rural settlements face different critical challenges in the current framework of rapid transformation. Tangible and intangible elements related to the traditional spatial organisation of siting and living are threatened by a socio-economic transition which appears to be indifferent to local specificities. Such aspects express and shape the rural built fabric, which shows no resistance to the pressures of both planned and spontaneous development. The few exceptions are mainly represented by the survived vernacular architectures, whose function goes beyond practical uses, such as the ancestral halls. Their spatial principles persisted in the malleable rural patterns, making such buildings the physical carrier of local traditions. This paper takes a rural village in the Fujian Province, China, as a paradigmatic case study to explore the settlement pattern's degree of resilience. The data collected in two years of fieldworks allows authors to assert the prominent role played by the fifteen ancestral halls of the village. After introducing the current patterns of change, with a focus on the phenomenon of rural hollowing, the paper emphasises both the spatial rules and the contextual relationships of vernacular buildings. In the conclusions, we remark their importance against the backdrop of current land use development, suggesting to reconsider the vernacular buildings as an alternative approach for more conscious and sustainable development.
\end{abstract}

\section{GOALS, CASE-STUDY AND METHODOLOGY}

\subsection{Goals}

Against the backdrop of the so-called Ecological Civilization, Chinese rural areas play a pivotal role to achieve a harmonious development able to mitigate the socio-economic disparities between rural and urban areas. Urbanizing the countryside, especially in the coastal regions, seems to be the dominant approach to alleviate poverty, optimize the use of land and boost local economies. From an architectural point of view, two aspects feature the current practices of rural development. The first is the definition of ideal settlement's schemes to allocate people, resources, infrastructures and services rationally (Bray, 2013; Rosenberg, 2013). The second consists of the integral protection of built heritage as drivers for the growing industry of domestic rural tourism ( $\mathrm{Li}, 2018)$. While it is clear that these elements are complementary, the mainstream ideas in design disciplines struggle to find points of interference, mainly due to the segmentation of investigations' fields, generating underexplored themes embedded in strategies of rural revitalization. One of these is the relationship between vernacular architecture - whose extent is today included in the broad notion of rural heritage - and the settlement's built form, which encompasses the traces of the historical civilization of local communities. This contribution pursues to bridge this distance considering the role of vernacular architectures in the definition and qualification of the settlement's built form in a rural village in the Fujian Province. We focus on how these forms of heritage can be mobilised to invigorate a development plan sensible to the local resources, physical and cultural.

\subsection{The case-study}

Zhangyang Village is a rural settlement of 1.500 inhabitants in the Fujian Province, connected with Putian City by a forty-minutes single-road driving. The village lies in a small plain surrounded by hills and crossed by a river. Like many others, the village features a socio- economic stratification which animates and gives shape to a diversified built environment. The heterogeneous built form determines the typical patchwork of shapes characterizing villages in coastal regions (Figure 1, Figure 2). In 2015, the village has been enlisted as a demonstration project of beautiful countryside construction. The former development project, proposed by a local SOE (state-owned enterprise), has been rejected by the village's authorities. Since then, a consultation's process between the local government and the Shanghai Jiao Tong University started. The new project, still under elaboration, focuses on three main directions: the creation of a local circular economy, and the re-organisation of the local industry's structure and the promotion of the touristic sector. The main goal is to mitigate the rural outflow migration of young generations, who pursue better job opportunities in the cities. The current village condition results from four decades of spontaneous development, led by the individual initiative. The ancient buildings went almost completely lost, except for the fifteen ancestral halls. These are interesting examples of historic vernacular architectures, whose spatial configuration plays a fundamental role in the determination of the settlement built form. These historic vernacular architectures embody the essence of local rural tradition and wisdom, which is also a core part of Chinese society in its association's modalities and ritual activities (Fei, 1992; Knapp, Kai, 2005).

\footnotetext{
* Corresponding author
} 


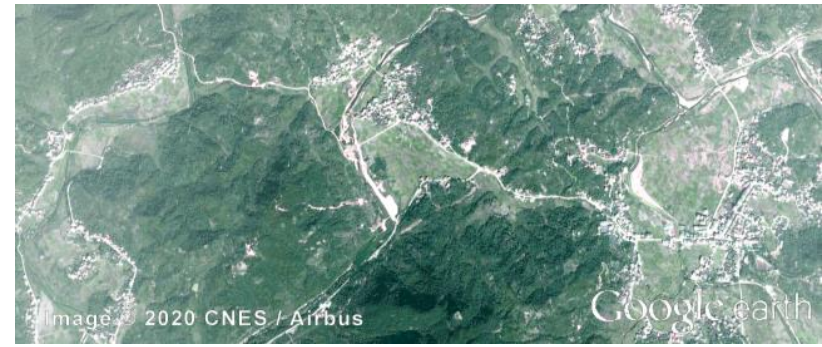

Figure 1. Satellite view of Zhangyang Village in 2019. Elaboration from Google Earth by the first author.

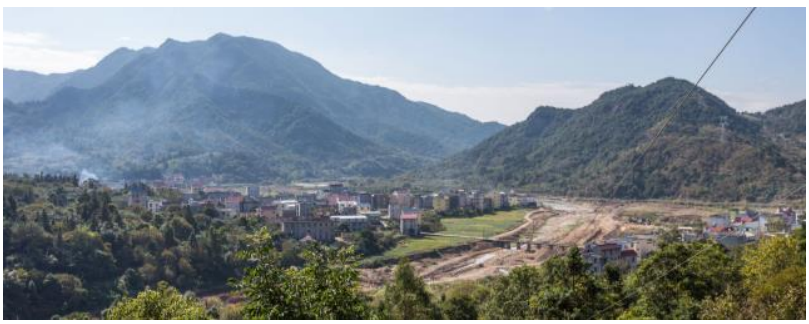

Figure 2. The village seen from Nazha Temple on Houyang Mountain. Photo by the first author.

\subsection{Methodology}

The study grounds on extensive fieldwork carried on by the first author in 2017 and 2018, which portrays the overall condition of the settlement with a particular focus on vernacular architectures (Figure 3). On-field observations and desk elaborations are the key-instrument adopted to explore the built form's spatial conditions. The buildings considered being the main document have been investigated, by means of the rigorous disciplinary tools of design disciplines, to study the development's patterns (paragraphs 3.1 Unplanned development and 3.2 Planned development) and the role of the vernacular architecture (paragraph 4.2 Spatial features of historic vernacular architecture) (Figure 4). Short dialogues with the local residents provided valuable information about the conditions of their own houses. To contextualize the results, we performed an extensive literature review, which is synthesised in paragraph 4.1 Literature review.

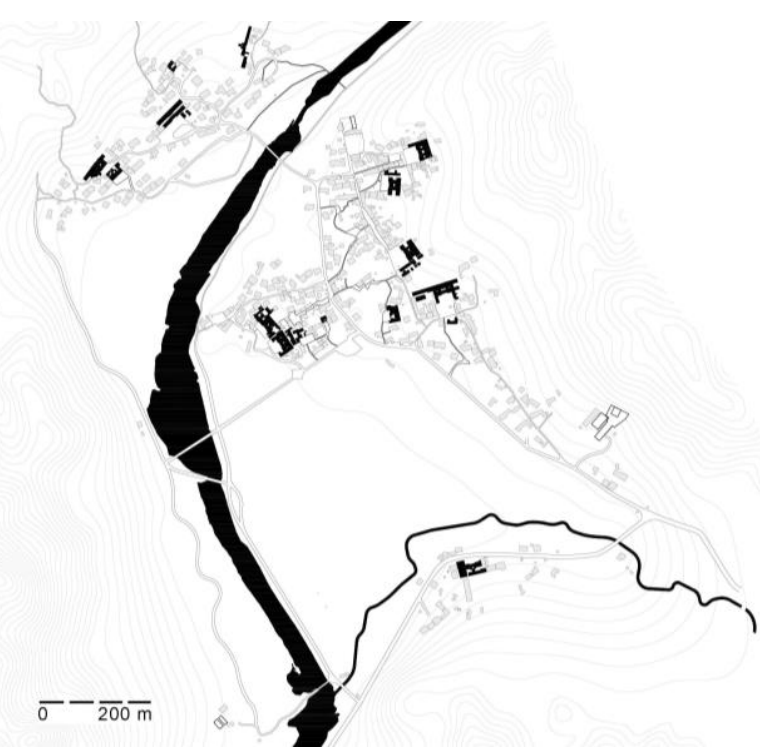

Figure 3. The fifteen ancestral halls. Elaboration by the first author.

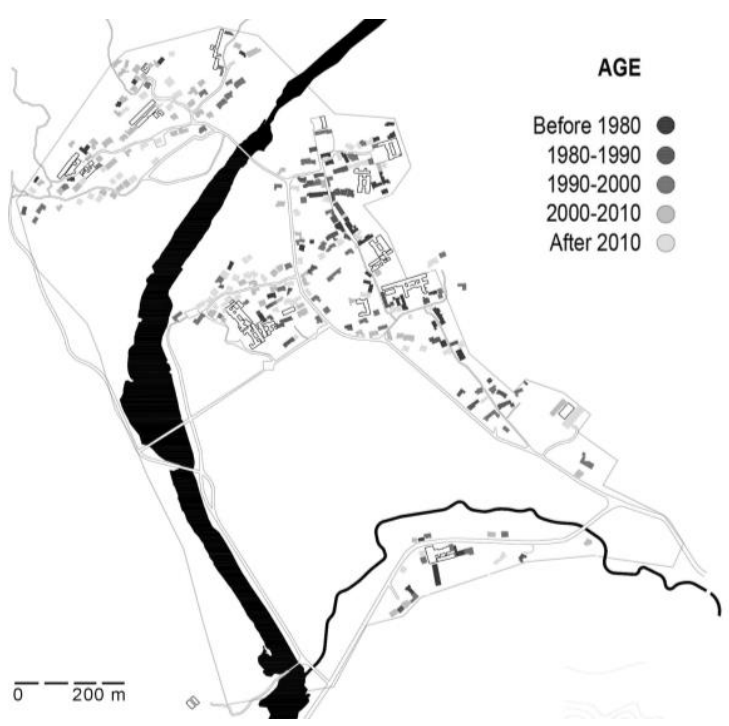

Figure 4. Buildings' period. Elaboration by the first author.

\section{INTRODUCING CHINESE RURAL DEVELOPMENT}

\subsection{Rural development since the Reform Era}

The Opening and Reform policies have boosted a new era in Chinese development, taking advantage of the domestic and foreign market's liberalization. At present China is facing a profound and intense socio-economic transition that is vigorously dragging the 'Middle Kingdom' in a leadership position among the developed countries' group. The urbanization process is the main driver of industrial development and economic growth (Friedmann, 2005; Chow, 2015; Hsing, 2010; Williams, 2017; Wu, Gaubatz, 2013; Fabris, Semprebon, 2019). Chinese megacities pictures shape the collective imaginary, leaving little space for the dramatic transitions occurring in rural areas. The countryside development is silently - but not less irreversibly compromising the historical relationships between natural resources and human life. In the last years, neologisms, like 'urban-rural continuum', 'informal' settlements and 'in-situ' urbanization or urbanization 'from below', have been coined or recalled to address that China is urbanizing its rural territories (Meriggi, 2018; Al, 2014, Zhu et al., 2013).

\subsection{Policies to promote rural development}

The measures released to stimulate rural development include the markets' opening via the de-collectivization, the 2016 abolition of the agricultural tax, and an imponent set of policies promulgated since the turn of the millennium, which culminate with the recent Five-year Strategic Plan for Rural Revitalization (2018-2022). The countryside renaissance is one of the top priority of Beijing's agenda. For instance, in the 2018 No. 1 Central Document, the call for "Rural Vitalization" is part of the "country's great rejuvenation". The document states that "there is quite a lot of work to be accomplished in Chinese villages, where opportunities for development have arisen as the country enters a new era." In principles, the document sets the guidelines for comprehensive planning in the countryside, considering multiple sectors of society, such as economy, politics, culture, society, ecology and Party construction. This strategy is addressed as a "historic task" that is essential to complete China's modernization. The document points out that by 2020 an institutional framework and policy system has to be established. Accordingly, within this year, both the poverty condition and rural productivity should be substantially 
improved. By 2035, 'decisive' progress should be accomplished, in terms of agricultural innovation and public services supplying. By 2050, China will have efficient agriculture, beautiful countryside and well-off farmers. The guiding ideology is to establish, according to the Confucian motto, a "moderately prosperous society" by following the idea that, before society reaches "great harmony", it has to experience the phase of "moderate prosperity". The concept has been introduced by President $\mathrm{Hu}$ Jintao, when referring to economic policies conceived to realize an equal distribution of resources. In parallel, the notion of 'environmental aesthetic' a concept re-discovering literature's classics and rural traditions - has been increasingly used in strict connection with the ideas of sustainable growth and Ecological Civilization (Chen, 2015). The Chinese development narrative started to sensitizing both domestic population and foreign observers, by re-positioning the national ambitions in an ecological framework. Despite the efforts of the central government, both the striking socioeconomic disparities (Whyte, 2010), and the unbalanced industrial development (Tilt, 2010) remain the principal obstacles to achieve a nation-wide inclusive and ecological development.

\section{PATTERNS OF RURAL DEVELOPMENT}

The physical transformation of Chinese ruralities can be seen as the tangible consequences of policies implementation. The case study of this paper offers the possibility of examining two development patterns. The first consists of the ongoing spontaneous development driven by the uncoordinated private initiative. The second corresponds with the planning development formalised by the local SOE.

\subsection{Unplanned development}

The key feature of the spontaneous development, in Zhangyang Village, is the fragmentation of the built form, given by the irregular distances between the buildings and their heterogeneous orientation. With few exceptions, the houses constitute the almost totality of the buildings. They fill the plain generating broken and unbroken sequences of built and unbuilt spaces (Figure 5 and 6). It is possible to recognize two expansion's patterns: a spot pattern and a diffusive pattern. The first corresponds with the construction of single buildings located in the denser built fabric. Due to the limitation of free space, the new houses are located in the interstitial spaces or replace existing structures. The spot pattern conflicts with the phenomenon of "hollow villages" - according to which the rampant urbanization is coupled with the abandonment of old houses (Liu et al., 2010; Sun et al., 2011; Gao et al., 2017) since it expresses the reluctance of farmers to abandon their dwellings. Preferring to settle in the village's core, they decide to demolish and rebuild their own house in the same place or in proximity. The spot pattern does not alter the urban fabric significantly, but increases the density of the built fabric, especially in the vertical dimension. The diffusive pattern locates in the fringe areas of the village and consists of the scattered addition of freestanding houses. This type of dwelling, also defined boxlike villa (Knapp, 2005), is the last stage of the typological evolution. The replication 'ad libitum' of this housing model introduced a new vertical dimension in the village and, at the same time, compromised the spatial relationships featured in the past by the dwellings and the ground. Farmers started building their house in the middle of concrete-paved yards which, fenced by walls, broke the spatial continuity between the domestic and the public spheres (Figure 7). Due to the evolution of the lifestyle, the dwellings pursue an ever-growing degree of intimacy, cutting the connections with the historical space of relation: the street. The propagation speed of the diffuse pattern impacts dramatically on the territory, determining both the massive loss of arable land and the impairment of the settlement's formal structure, as well as its (past) charming image.

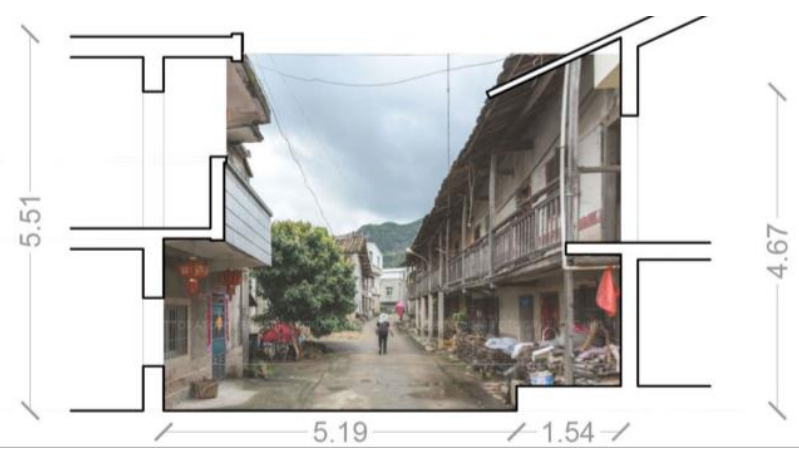

Figure 5. Urban sections showing the consistency of the built form. Source: elaboration by the first author.

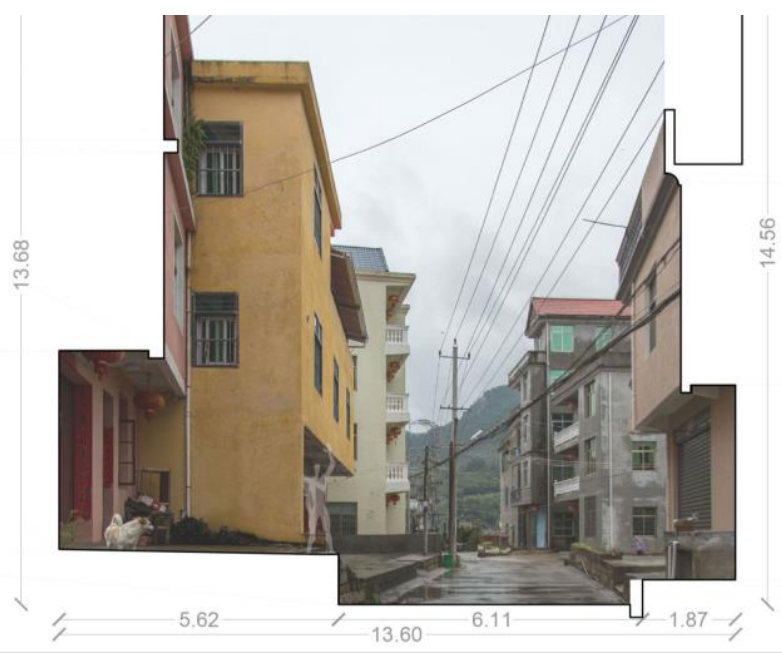

Figure 6. Urban sections showing the consistency of the built form. Source: elaboration by the first author.

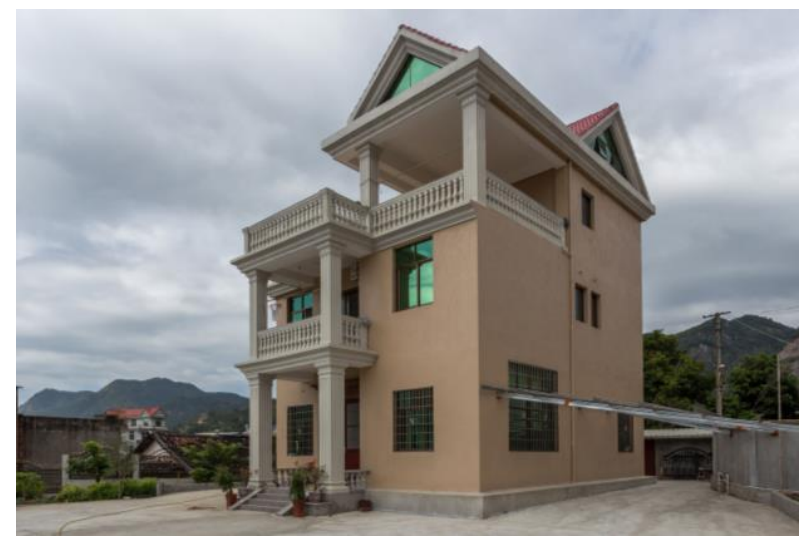

Figure 7. Sample of a recently built boxlike villa. Photo by the first author.

\subsection{Planned development}

The planned development follows the principles of land consolidation - a concept implemented to optimize the land's productivity (Long, 2014) - and proposes the almost total demolition and reconstruction according to a unified style. The 
urban-like form is drawn over the same sediment of existing buildings, rectifying the existing irregularities. The volumes are concentrated in rows of buildings which pull together arrays of bi-familiar detached villas. What emerges is an imposed layout, organized in a rigid grid, and insensible to the contextual specificities. The middle-rise houses are equipped with little gardens in front of the main dwelling's entrance. The few housing typologies as well as their style are repeated everywhere, without elements of discontinuity, resulting in a monotonous and redundant built form. Looking at the scale of architecture, the aesthetic values put in this project are poor and denote a scarce devotion to the improvement of the settlement's spatial quality. By inspecting the rendering of the planned development, the existing buildings are demolished and re-built with similar layouts and characteristics.

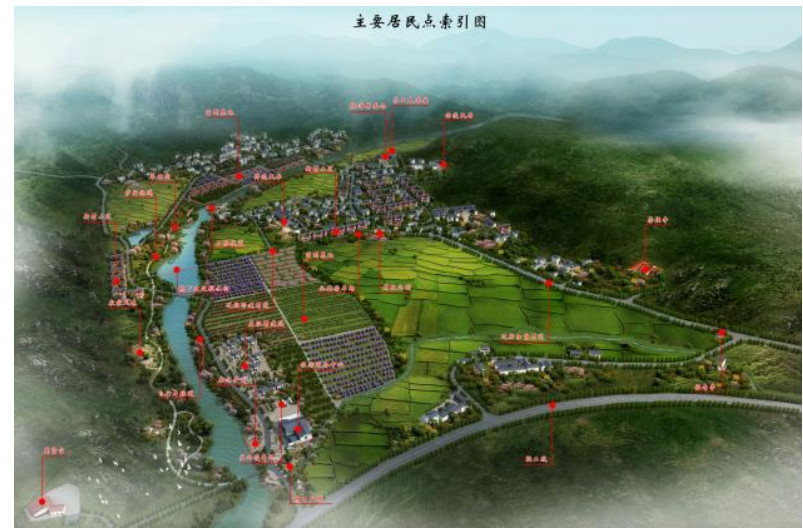

Figure 8 . Bird view of the rejected proposal. Source: courtesy of the local government.

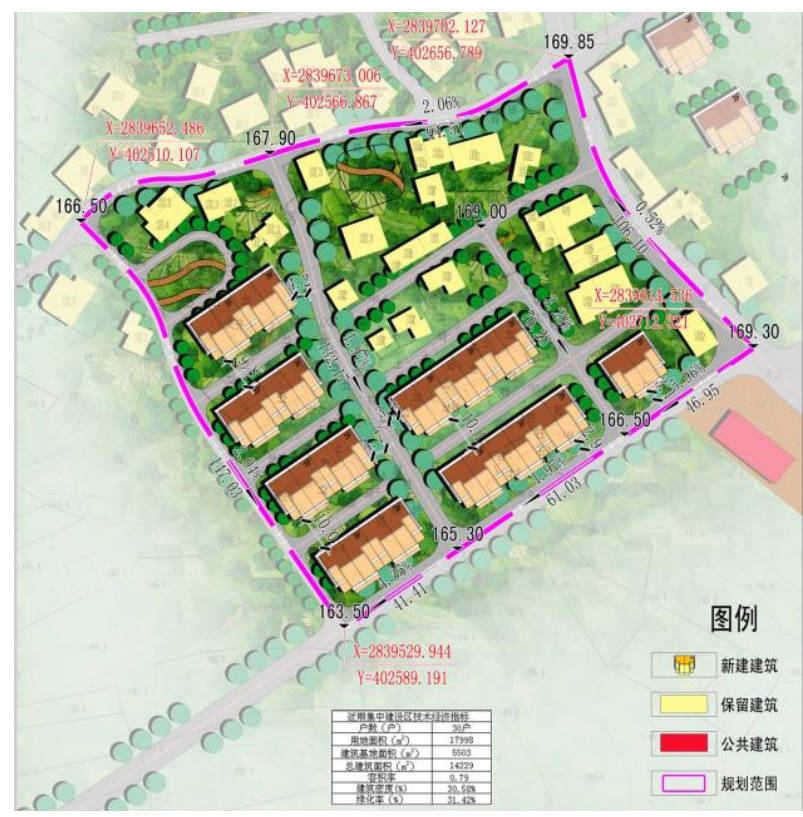

Figure 9. Plan of the rejected proposal.

Source: courtesy of the local government.

\section{RESULTS}

The fifteen traditional buildings are hybrids architectures which mix multiple purposes. Alongside with dwelling, spiritual and secular function are embedded, namely the worshipping of forefathers and the harvest's processing. While the latter is a common attribute for rural buildings, the first function determines that distinctive aspect that makes these fifteen buildings different from the others. Thus, according to the rites performed in the main chamber, such kind of construction is called "ancestral hall" or "family shrine," even though the divinatory practices are not the only activities performed in its inner spaces. Before presenting their spatial features, we recall those sources that have contributed to conceptualize the architecture of ancestral halls.

\subsection{Literature review}

Probably, the "Classic of Lu Ban,” 魯班經, 'Lu Ban jing', that is a carpentry manual wrote in the fifteenth century and based on the mythological figure of $\mathrm{Lu} \mathrm{Ban}$, is the most accurate source of information. In consideration of local land's conditions, the text provides carpenters with a list of favourable and unfavourable ways of siting and building a house. In his well-known translation (1993), Ruitenbeek remarks that the ' $\mathrm{Lu}$ Ban jing' 'deals with much more humble buildings: dwelling houses, stables, granaries, and an occasional family shrine. For this vast, predominantly rural, and almost wholly anonymous sector of building, the Lu Ban jing is a most important primary source. More than any other document, it provides insight into the complex whole of ideas and techniques which for the Chinese constituted architecture." Being the ideal set of family rituals, the ancestral hall embodies many aspects of Confucian thinking, including Chinese geomancy, generally known as 'fengshui' (Coggins, 2014; Obringer, 2005; Wei, 1992, Faure, 1986; Xing, 2006; de Groot, 1910). Ho provides an introduction to the architecture of an ancestral hall (2005) considering those buildings serving only for family ceremonies, gatherings and rites. Ho's contribution is nonetheless significant since, as he argues, the ancestral halls in remote rural settlements had multiple purposes and had been usually constructed with simple typologies, erected with rammed-earth walls and timber frames structures supporting low-pitched roofs, but not less articulated than the official ancestral halls in terms of spatial composition. $\mathrm{He}$ accurately lists the several rites taking place in the family shrines and how such forms of routines contribute to the determination of the building's architecture. Beyond being sites imbued with dense genealogic meanings, Chen (2018) illustrates the closed relationship between family shrines' architectures and the environment as elements "being part of the landscape," according to its etymological definition of 山水, 'shanshui', namely mountains-and-water (Knapp, Dongqi, 1992). The climatic conditions play a pivotal role in the determination of both the volumetric composition and the distribution schemes as well as the degree of permeability of the envelope. Recent studies demonstrate the correlations between the climate and the permeability in vernacular ancestral halls, like most of the buildings in Fujian, which tend to be open ensuring the circulation of fresh air (Wang et al. 2016). A crucial element of vernacular architecture in hot and humid climates like Fujian's one is the skywell, namely 天井, 'tianjing', that provides ventilation and shadow (Hammond, 1992). Considering the social meaning of this building, it is worthy to remark that Chinese families are essentially corporate entities and operate into society as the basic unit of production and consumption (Jervis, 2005). As a family residence, the building provides an array of spaces dedicated to the family's economy, mainly agricultural.

\subsection{Spatial features of historic vernacular architectures}

Zhangyang Village has fifteen traditional buildings which share common uses and spatial features. Even though they mix different functions, the most important one is the divination via 
rituals. Thus, we name them ancestral halls, aware that they have distinctive characters compared to other ancestral halls throughout China. The fifteen ancestral halls of Zhangyang Village are organized on a $\mathrm{C}$-shaped layout which defines a paved yard in front of the entrance (Figure 10). The adopted technologies, rammed earth for the walls and timber frame for the roof, determine the geometric grid defining the envelope and the structure. The main body has a linear development and hosts three arrays of rooms separated by two corridors, which flow into a small cross-shape courtyard. This atrium, characterized by a skywell and an impluvium, connects the external front yard with the altar chamber (Figure 11). This patio serves both for distributing to the other rooms and for the clan's activity, like rituals, disputes, punishments and gatherings. The architectural configuration of pavements, columns, wall and roofs, the game of lights and shadows originated by the natural illumination, the presence of divinatory instruments, propitiatory characters and genealogic trees, and the unbroken silence experienced when entering, make this space solemn and mystic at the same time. The atrium is the distinctive part of the building and repeats in all the ancestral halls, showing similar characteristics (Figure 12). The front elevations share common features too, such as the presence of stoned podiums, wooden galleries, and timber or stoned columns sustaining the portico, all mirrored in correspondence of the main axis. The result of the structural symmetry and axiality in the plan composition has originated gradually. What in the past represented a single family, perhaps migrating from other regions, overtime ended up representing a whole clan. Each descendant has implemented the system set by the first ancestor by adding units in continuity with existing structures or realizing new pavilions in the close proximity of the family shrines. This is confirmed by recent anthropological surveys conducted in the Putian plain, which explained that, in most of the villages, ancestral worships were carried out in the old forefathers' homes (Dean, Zhen, 2009). The progressive addition of new parts took place without invading the rectangular open space in front of them and revealing a strong spatial principle able to resist to the recent urbanization waves. This open space has a crucial role in the family's domestic routine. It is a semi-public area connecting the street with the house - which hosts several functions, including the food's processing and storing. The importance of the front yard arises clearly through the disposition's principles of the buildings realised in the recent period. The new dwellings respected the rectangular shape of the yard, locating at its edges and ensuring the view contact between the inner ritual space and the landscape (Figure 13).

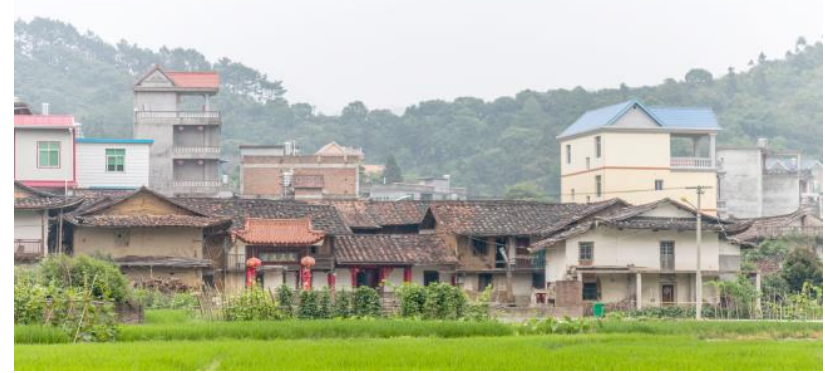

Figure 10. One of the fifteen ancestral halls. Photo by the first author (2018).

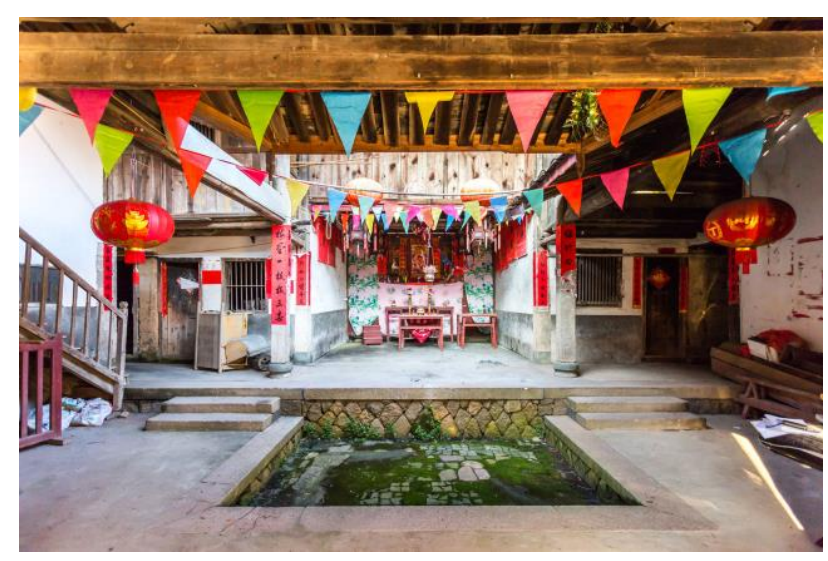

Figure 11. The impluvium and the skywell in front of the family altar. Photo by the first author (2018).

The graphic comparison among the fifteen ancestral halls clarifies how these spatial principles and their proportions repeat, rising as strong invariants of the space in the settlement built fabric.

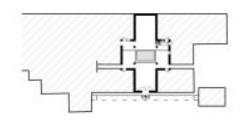

H05
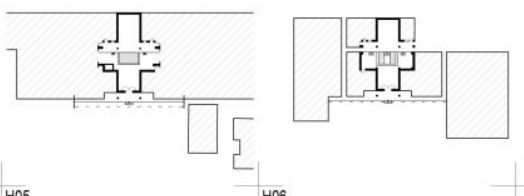

HO6
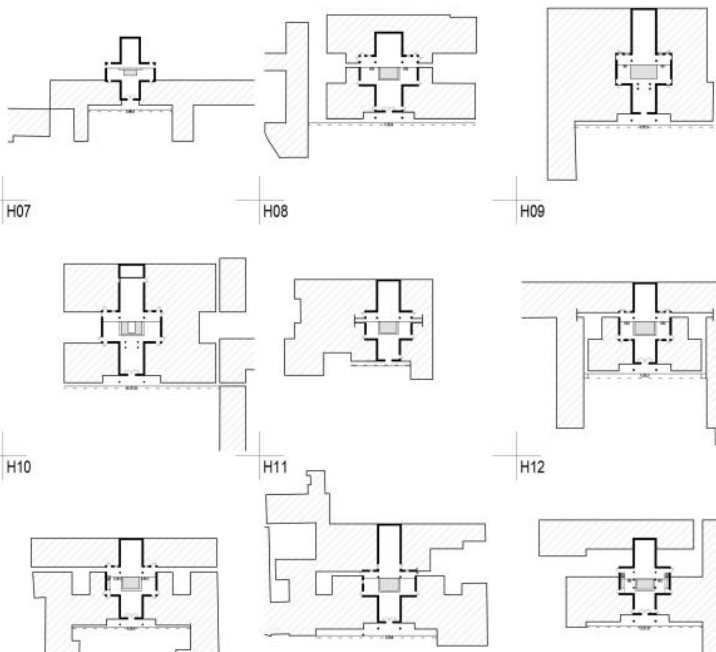

$H 12$

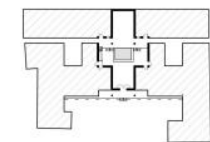

$\mathrm{H} 13$

H14
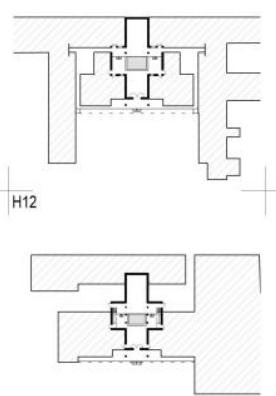

(1)
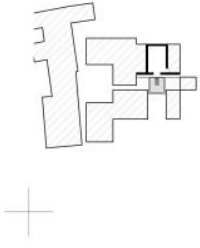

Figure 12. Comparative sch
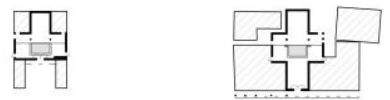

$50 \mathrm{~m}$

I

the first author. 


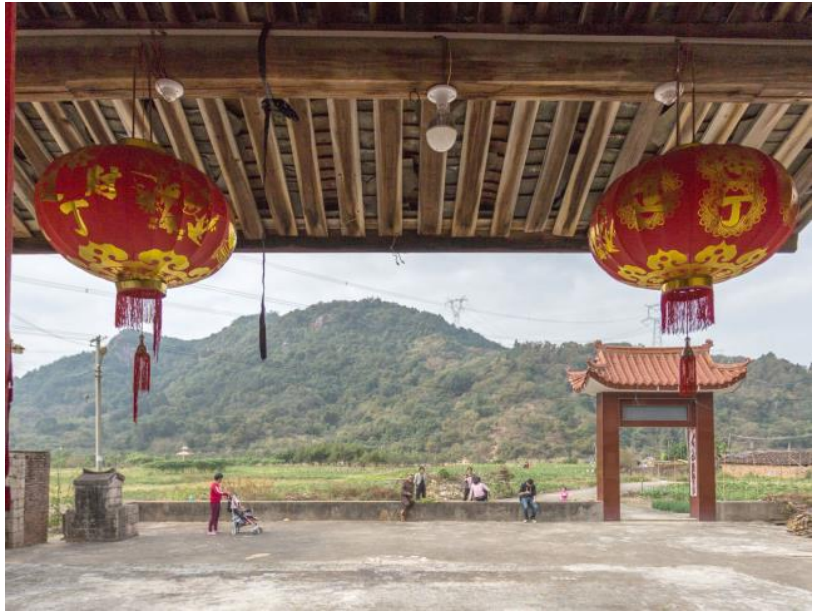

Figure 13. The front yard in front of the ancestral hall. Photo by the first author (2018).

\section{DISCUSSION}

\subsection{From spontaneous development to rural hollowing}

After thirty years of forced collectivization, the introduction of the Household Responsibility System in the early 1980s has affected the intensity of farming activities, making peasants responsible for their profits and loss. As a consequence, the crops' production increased considerably, securing unprecedented revenues available to be employed in housing enlargement or construction. The private initiative and the will to exhibit the reached new social class stimulated a spontaneous bottom-up urbanisation process, without the direction of any overall planning (Knapp, Dongqi, 1992). In the meantime, the farmland located in the fringe areas of villages started to be seen as a land available for housing construction, considered to be the most profitable use. The socio-economic transition of Chinese ruralities coupled with the assimilation of unprecedented scales of values and aspirations. These, in turn, reflected on the architectural expression of the new houses, generating, as in the case of Zhangyang, awkward combinations of vernacular shapes, greek-style loggias and baroque ornaments. Peasants moved into the newly built dwellings, leaving vacant the old ones in the centre of the village. This phenomenon, labelled as "rural hollowing," can be traced in thousands of rural settlements. Although it presents the problems of soil consumption and housing abandonment, the village hollowing still offers the possibility of considering the spatial resources inherited from the traditional rural past as elements able to identify places and communities. The importance of such traditional elements is written in the built form and is readable in the physical setting of the local 'cultural landscape'.

\subsection{The risks of insensible planned development}

As part of the orthodox policy implementation, the planned development introduced in paragraph 3.1 Planned development can be assumed as paradigmatic of a worrying condition interesting a considerable number of rural redevelopment projects (Bray, 2013; Rosenberg, 2013). The extensive demolition and reconstruction suggest that the planned development of Zhangyang Village would determine both the enhancement of the service industry but also the imposition of a homogeneous suburban model, threatening the aesthetic and cultural values typical of rural settlements. In our opinion, the lack of a critical approach to architectural and urban design - which are relegated to the role of shape-givercreates the basis for fast but indifferentiated development of land. In particular, the comforting procedures of land optimization may represent an obstacle to a more sensible and site-specific development. As in the case of Zhangyang, many planned proposals reveal a profound lack of interest to the context, whose traces coming from past, have been cancelled or ignored. Even when the project aims and achieves to concentrate the residential area, the built form, resonating as a urban peripheral expansion, determined enormous losses in terms of intangible heritage. (Semprebon, Fabris, 2019; Long et al., 2010; Alhers, Schubert, 2009) (Figure 14).

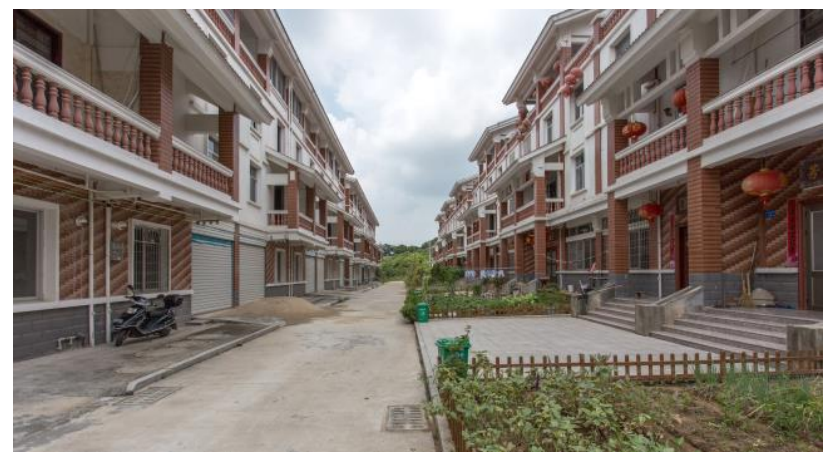

Figure 14. Example of a rural development: Jiankou Happy community, Putian City, Fujian Province. Photo by the first author.

\subsection{The ancestral halls as forms of resilience}

The presence of fifteen ancestral halls in a settlement populated by four clans witnesses the will by young members in declaring their independence from ancestors or brothers, claiming for new identity and determining a form of branching. As remarked by Ho, "The most conspicuous buildings found in village landscapes in southern China are usually ancestral halls, architectural statements of the strength of lineages whose existence extends the concept of familyism beyond individual families to include all those sharing a common patrilineal descent from a single ancestor" (2005). Beyond the socio-cultural context, their importance extends to the settlement built form. Like matrices, they characterise the built fabric morphology. Even though the vernacular buildings appear suffocated by the waves of recent urbanisations, their presence suggests a non-written system of morphological rules impressed in the built texture. Such rules and invariants entwine inextricably with the topography and deeply permeate the local physical and cultural landscape (Figure 16). From this perspective, the spatial configurations of the fifteen ancestral halls have endlessly represented a manifestation of built form resilience, where a sequence of spatial situations has actively reacted to its dissolution. Evidence of recent demolitions, additions, and contaminations appears to have not totally compromised the spatial structure of the historic vernacular buildings. Therefore, we argue that their historical trajectory should not vanish with the imposition of new planning schemes, which risk to flatten such a cultural distinctiveness. The architectural principles of vernacular buildings could be considered as an essential element of dialogue to be taken into account for the proposals of new design strategies of local development. For example, Seghezzi and Panta Bellido (2020) presents an architectural proposal for a Research Center in Zhangyang Village, grounding their design in the spatial reinterpretation of the composition principles which characterise the fifteen ancestral halls (Figure 17). 


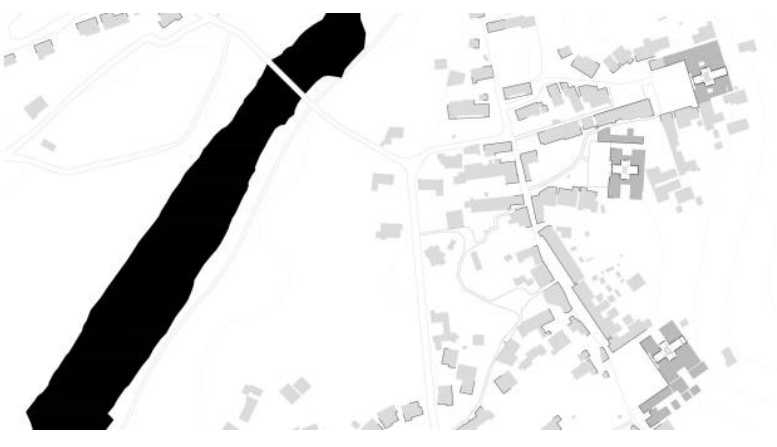

Figure 15. The spatial principles of vernacular architecture in relation to the built form. Elaboration by the first author.

\section{CONCLUSIONS}

6.1 Vernacular architecture as possible driver of local development

In this paper, we have presented the current patterns of change taking place in a rural settlement, focusing on the essential role played by the survived vernacular architectures in determining the morphology of the built fabric. The dilapidation and abandonment of such buildings can be read as a consequence of 'rural hollowing'. Both the local administration and the inhabitants have been reluctant to protect these traditional buildings. They were conceived respectively as limitations to formulas of land consolidation - via extensive demolition and re-construction - and as symbols of a humble past from which inhabitants aim to emancipate. The historic vernacular architectures struggle with modern dwellings to be still considered idoneous places to inhabit. However, the role that rural and cultural tourism is acquiring in the domestic economy (Pola, 2019) put historic vernacular architecture in a new framework where the exhibition of traditional lifestyle entails the survival of ancient buildings. Indeed, as remarked by Lincoln and Madgin (2018) the notion of Beautiful China entangled in the rural revitalization policy "creates space for heritage protection" and, as we want to stress, sensitive development. The strategies oriented to a more cautious development sensible to vernacular architecture are countless. In our opinion, these strategies should retain the continuative use of those buildings as a prerogative to question the belief that fast change implies fast improvement.

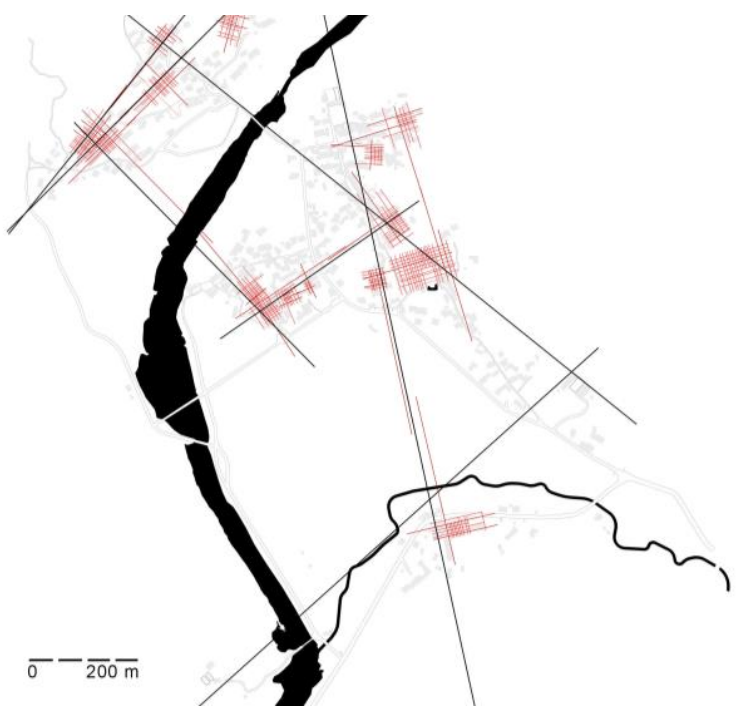

Figure 16. Spatial correspondences of the vernacular architectures. Elaboration by the first author.
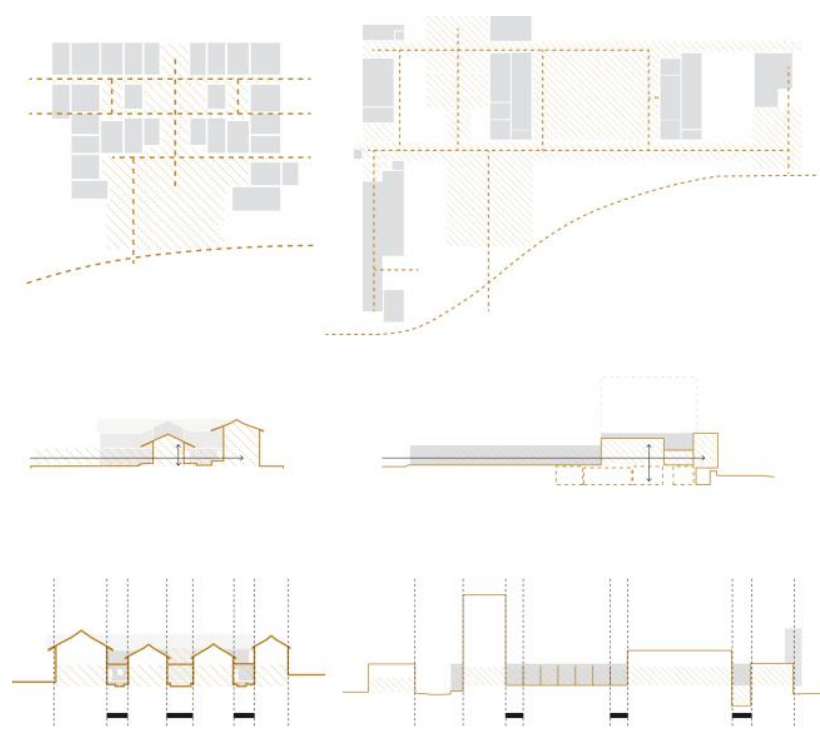

Figure 17. The architectural project for a new Research Center in Zhangyang Village reinterprets the spatial principles of the ancestral halls. Image by Seghezzi and Panta Bellido, 2020.

\section{REFERENCES}

Al, Stefan, 2014: Villages in the city. A guide to south china's informal settlements. Hong Kong University Press, Hong Kong. Chow, R. Y., 2015: Changing Chinese cities. The potentials of field urbanism. NUS Press, Singapore.

Ahlers A. L., Schubert G., 2009: "Building a New Socialist Countryside" - Only a Political Slogan? Journal of Current Chinese Affairs 38 (4), 35-62.

Bray D., 2013: Urban Planning Goes Rural. Conceptualising the "New Village." China Perspectives 3, 53-62.

Chen, K., Li Y., Cao Y., 2018: A Study on the Space Characteristics of Ancient Ancestral Temples in the Taiping District of East China. Journal of Asian Architecture and Building Engineering 15 (13): 365-372.

Chen, W., 2015: Chinese environmental aesthetics (Cipriani, G., ed., Su, Feng Trans.). Routledge, London.

Chow, R. Y., 2015: Changing Chinese cities. The potentials of field urbanisms. NUS Press, Singapore.

Cogging, C., 2014: When the land is excellent. Village feng shui forests and the nature of lineage, polity and vitality in southern China, In Miller, J., Yu, d. D., van der Veer, P. (eds.), Religion and Ecological Sustainability in China. Routledge, London, 97.

Corboz André, 1985: Il territorio come palinsesto, Casabella $516,22-27$

de Groot, J. J., 1910: The Religious System of China, Brill: Leiden.

Dean, K., Zheng Z., 2009: Ritual Alliances of the Putian Plain. Volume One. Brill, Leiden, 219. 
Fabris, L. M. F., Semprebon, G., 2019: The Chinese 'high and slender' condominium. Techne - Journal of Technology for Architecture and Environment, 17, 104-113.

Fei, X., 1992: From the soil. The foundations of Chinese society. University of California Press, Berkeley.

Friedmann, J., 2005: China's urban transition. University of Minnesota, Minneapolis.

Faure, D., 1986: The structure of Chinese rural society: lineage and village in the eastern New Territories, Hong Kong. Oxford University Press, Oxford.

Gao, X., Xu, A., Liu, L., Deng, O., Zeng, M., Ling, J., Wei, Y., 2017: Understanding rural housing abandonment in China's rapid urbanization. Habitat International 67, 13-21.

Hammond, J., 1992: Xiqi Village, Guangdong: Compact with Ecological Planning. in: Knapp, R. G., (edit by), Chinese Landscapes: The Village as Place. University of Hawaii Press, Honolulu, 100.

Hsing, Y., 2010: The great urban transformation. politics of land and property in China. Oxford University Press, Oxford.

Ho P., 2005: Ancestral Halls. In Knapp, R. G. and Lo, K., (eds.), House, home, family. Living and Being Chinese, University of Hawai'i Press, Honolulu. 295-323.

Jervis, N., 2005: The meaning of jia. An introduction. In Knapp, R. G. and Lo, K., (eds.), House, home, family. Living and Being Chinese, University of Hawai'i Press, Honolulu. 223-234.

Knapp, R. G., Dongqi, S., 1992: Changing Village Landscape, in: Knapp, R. G., (edit by), Chinese Landscapes: The Village as Place, University of Hawaii Press, Honolulu, 66.

Knapp, R. G., Lo, K. (eds.), 2005: House, home, family: Living and being Chinese. University of Hawai'i Press, Honolulu.

Li X. (ed.), 2018: Building a future countryside. Catalogue of the Chinese pavilion at the 16th Biennale of Venice Architectural International Exhibition. The Image Publishing Group / ACC Art Books, New York.

Lincoln, T., \& Madgin, R., 2018: The inherent malleability of heritage: creating China's beautiful villages. International Journal of Heritage Studies, 24(9), 938-953.

Liu, Y., Liu, Y., Chen, Y., Long, H., 2010: The process and driving forces of rural hollowing in China under rapid urbanization. Journal of Geographical Sciences 20 (6), 876999.

Long, H., Lu, Y., Li, X., Chen, Y., 2010: Building new countryside in China: A geographical perspective. Land Use Policy 27, 457-470.

Long, H., 2014: Land consolidation: An indispensable way of spatial restructuring in rural China. Journal of Geographical Sciences 24(2), 211-225.

Meriggi, M., 2018: L'architettura del continuo urbano-rurale in Cina: Insediamenti hakka nel Guangdong orientale. Araba Fenice, Torino.
Obringer, F., 2005: Fengshui, or the Search for a Very Human Dragon, Diogenes 52 (3), 55-63.

Pola, A., 2019: When heritage is rural: Environmental conservation, cultural interpretation and rural renaissance in Chinese listed villages. Built Heritage, 2, 64-80.

Rosenberg L., 2013: Urbanising the rural: Local strategies for creating 'new style' rural communities in China, China Perspectives 3, 63-71.

Ruitenbeek K. (transl.), 1993: Carpentry and building in late imperial China: a study of the fifteenth-century carpenter's manual Lu Ban jing. Brill, Leiden, 81.

Seghezzi F., Panta Bellido, K. R. 2020. Rural Edge. Project for a Research Center in Zhang Yang Village, Fujian Province, China. Master Degree in Architecture Thesis, Supervisors Bovati, M., Semprebon, G., Politecnico di Milano 2020.

Semprebon, G., Marinelli, M., Valente, I., 2019: Towards design strategies for requalifying the rural: A comparative study of hollow settlements in China and Italy. 2019 XJTLU International Conference: Architecture Across Boundaries, KnE Social Sciences, 1 (2019), 195-208.

Semprebon, G., Fabris, L. M. F., 2019: Shaping a future countryside. Light and shadow on rural settlement's models in Chinese urban-rural continuum. Housing Environment 26, 4551.

Sun, H., Liu, Y., Xu, K., 2011: Hollow villages and rural restructuring in major rural regions of China: A case study of Yucheng City, Shandong Province. Chinese Geographical Science 21 (3), 354-363.

Tilt, B., 2010: The struggle for sustainability in rural China. Columbia University Press, New York.

Wang, H., Pu X., Wang R., Zeng Y., Qi X., 2016: A Study on Closed Halls in Traditional Dwellings in the Jiangnan Area, China. Journal of Asian Architecture and Building Engineering, 15 (2), 145.

Wei, F., 1992: Village Fengshui Principles, in Knapp, R. G. (edit by), Chinese Landscapes: The Village as Place. University of Hawaii Press, Honolulu, 38.

Whyte, M. K., 2010: One Country, Two Societies. Rural-Urban Inequality in Contemporary China. Harvard University Press, Cambridge, MA.

Williams, A., 2017: China's urban revolution. Understanding Chinese Eco-cities. Bloomsbury, London.

Wu, W., Gaubatz, P., 2013: The Chinese City. Routledge, London and New York.

Xing R., 2006: Allegorical Architecture: Living Myth and Architectonics in Southern China. University of Hawai'i Press, Honolulu, 78.

Zhu, Y., Lin, M., Lin, J., Chen, J., 2013: The extent of in situ urbanisation in china's county areas: The case of Fujian province. China Perspectives, 95(3), 43-52. 